\title{
160. On the Presence of 2,5-Dihydroxyphenyl Pyruvic Acid in the Urine of Diffuse Collagen Disease Patients
}

\author{
By Nagao Nishimura, ${ }^{*}$ Y Ykio Shibata, ${ }^{* *}$ Masataka YASUI,*) \\ and Hisashi OKАмото*) \\ (Comm. by Y. КotaKe, M.J.A., Nov. 12, 1956)
}

The term diffuse collagen disease was first applied in 1942 by Klemperer, Baehr, and Pollack ${ }^{1-4)}$ to an extensive pathological involvement found anatomically in the connective tissues and especially to a group of maladies, the salient feature of which is the abnormalities of its extracellular components. Acute rheumatic fever, rheumatoid arthritis, periarteritis nodosa, acute disseminated lupus erythematosus, diffuse scleroderma, dermatomyositis, and Weber-Christian's disease are usually included in this group. It is also suggested that thromboangitis obliterans, malignant nephrosclerosis, and subacute bacterial endocarditis are of similar type. There is some possibility, too, that certain examples of Henoch-Schönlein's purpura and Osler's erythema of dermal lesions with visceral manifestations may be classed to belong in this category.

In general, connective tissue (fibrils and ground substances) can react to injury in three basic ways; by degeneration, by fibrillar augmentation, and by reactive cellular proliferation. The feature of the degeneration is what is called fibrinoid degeneration and often leads in an extreme case to necrosis, while the fibrillar augmentation results in the proliferation of fibrils and the sclerosis of the tissue.

With these three basic reactions interwoven with each other, the morbid changes anatomically observable in collagen disease are very complicated, but for all that, it is considered that fibrinoid degeneration is the common denominator morphologically. Hitherto, collagen disease has been studied chiefly from either an anatomical or cytochemical viewpoint, with not a few discoveries obtained therefrom, but as Klemperer aptly states, the visible pathological changes in the collagen tissues are nothing but the manifestations of profound lesions, both chemical and physiological. A mere morphological observation, therefore, is by no means enough to reveal which of the three basic reactions is its true etiological factor in a given case. Thus, it becomes necessary to study the disease afresh from a biochemical angle. In point of fact, there is at present, very scanty literature in this line of study. The only worthwhile reports available are one by

*) Department of Dermatology and Urology of Wakayama Medical College.

**) Biochemistry Department of Wakayama Medical College. 
Rollett in which he states that the stroma of connective tissue contains tyrosine, and another by Klemperer, Gueft, and $\mathrm{Lee}^{5)}$ in which they hold that hematoxylin-staining body of acute lupus erythematosus has a strongly positive Millon reaction and that a fairly large amount of arginine is to be found in fibrinoid.

With regard to intermediary metabolism of phenylalanine and tyrosine there remains much to be confirmed yet, but the schema prepared by Neubauer ${ }^{6779)}$ from his experimental results of the urine of alcaptonuria is generally considered to represent their normal metabolic processes. The diseases, considered to be due to metabolic blocks of the intermediary metabolism of phenylalanine and tyrosine, are phenylketonuria, albinism, tyrosinosis, alcaptonuria. All of these diseases arise from a very rare and inherent error.

The writers of this paper happened in the course of our researches to detect in the urine of a dermatomyositis patient a substance identifiable unmistakably to be 2,5-dihydroxyphenyl pyruvic acid (to be abbreviated to 2,5-D.H.P.P.A. hereafter), which is, imaginarily, an intermediary metabolite of phenylalanine and tyrosine. The finding was further re-experimented and confirmed with 38 collagen disease patients by examining their urine. A test of $l$-tyrosine dosage was also performed, resulting in the aggravation of the lesions.

Experiments and results. Identification of 2,5-D.H.P.P.A. ${ }^{8)}$

Either as it was or acidified with $10 \%$ sulfuric acid, the 24-hour urine of diffuse collagen disease patients was concentrated till about $20 \mathrm{cc}$ of it remained, and after another further treatment of it with $60 \%$ alcohol and the resultant elimination of inorganic salts, the urine thus obtained was subjected to experiment. Then, one-dimentional paper-partition chromatography (P.P.C.) was performed by making use of No. 52 Toyo filter paper.

Developer. (A) n-Butanol : acetic acid : water $=4: 1: 1$. (B) $n$ Butanol saturated with water and added with 2 or 3 drops of formic acid (the $\mathrm{Rf}$ value of each spot in this case is shown brackets). Developing time: 12 hours.

Results.

1) Rf value. Neutral urine-chiefly spots of $\mathrm{Rf}$ value 0.45 (0.25). Acidified and concentrated urine-chiefly spot of Rf value 0.25. Synthetic 2,5-D.H.P.P.A. - spots of $\mathrm{Rf}$ value $0.45(0.25)$ and 0.25 .

2) Fluorescence color. Fluorescence color of these spots-purple.

3) Color-reaction of chromatograms. On examination of the colorreaction of these spots, the following results were invariably obtained (Table I). 
Table I

\begin{tabular}{|c|c|c|}
\hline Reaction & Result & Identification \\
\hline 1. Brigg's reaction & + & Phenolic compound \\
\hline 2. Ammoniacal silver reaction & + & $\begin{array}{l}\text { Compound with either -CO or } \\
\text {-CHO present }\end{array}$ \\
\hline $\begin{array}{l}\text { 3. Hydrazone reaction } \\
\text { (2,4-dinitrophenylhydrazine } \\
\text { in } 2 \mathrm{~N}-\mathrm{HCl})\end{array}$ & + & $\begin{array}{l}\text { Compound with either - } \mathrm{CO} \text { or } \\
\text {-CHO present }\end{array}$ \\
\hline 4. $\mathrm{FeCl}_{3}$ reaction & $\begin{array}{l}\text { Yellowish- } \\
\text { brown }\end{array}$ & $\begin{array}{l}\text { Phenolic compound, not phenol } \\
\text { itself }\end{array}$ \\
\hline
\end{tabular}

The fluorescent spots of each $\mathrm{Rf}$ value were next cut out and eluted in $\mathrm{pH} 7.2$ phosphate buffer. The solution thus prepared was put to the test and in each case, results such as are shown in the following were invariably obtained (Table II).

Table II

\begin{tabular}{ll|cl}
\multicolumn{1}{c|}{ Reaction } & Result & \multicolumn{1}{c}{ Identification } \\
\hline 1. Fenton reaction & + & Hydroquinone derivative \\
2. Hydrazone reaction & + & $\begin{array}{c}\text { Compound with either -CO or } \\
\text {-CHO present }\end{array}$ \\
\hline
\end{tabular}

As for the ultra-violet absorption spectrum test of these spots, the substances in the urine could be considered to be identical with the synthetic sample in its results.

In the paper-partition chromatographic and ultra-violet absorption tests of crystallized $p$-hydroxyphenyl pyruvic acid, however, the results obtained $(\lambda \max 290 \mathrm{~m} \mu \mathrm{Rf} 0.75$ ) proved quite different, as shown above. From these experimental results, therefore, it is beyond doubt that the substances obtained from the urine of collagen disease patients

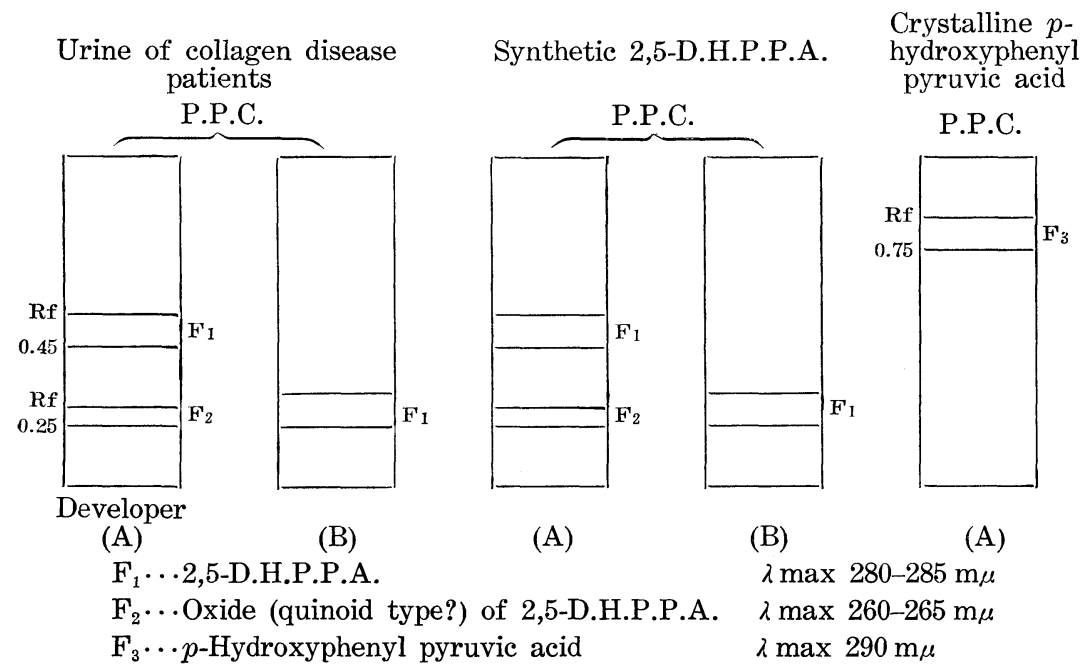

Paper-partition chromatography (P.P.C.) and ultra-violet absorption spectrum 
can be identified with 2,5-D.H.P.P.A. and its oxide (quinoid type?). Apart from this, a crude crystallized aculeate form of reddish-yellowishbrown substance (m.p. $195^{\circ} \mathrm{C}$ ) presumable to be phenylhydrazone of 2,5-D.H.P.P.A. was obtained, which is now under further examination. The urine of collagen disease patients, if left exposed, was found to assume a reddish brown color. This is worthy of note, since it may signify that most of 2,5-D.H.P.P.A. in the urine changes into a quinoid type as in the case of the urine of alcaptonuria.

Clinical results. Collagen disease patients: The results, as shown below, were positive without a single exception (Table III).

Table III

\begin{tabular}{|c|c|c|c|}
\hline & Disease & Number of examinees & Result \\
\hline & Acute disseminated type & 1 (1 female) & Positive \\
\hline Lupus & Subacute disseminated type & 4 ( 2 males and 2 females) & , \\
\hline matosus & Chronic disseminated type & 4 ( 1 male and 3 females) & , \\
\hline & Chronic discoid type & 1 (1 male) & ," \\
\hline Diffuse $s$ & cleroderma & 5 (5 females) & ," \\
\hline Dermato & myositis & 2 ( 1 male and 1 female $)$ & , \\
\hline Weber-C & hristian's disease & 2 (2 females) & ," \\
\hline Periarter & itis nodosa & 2 ( 1 male and 1 female) & ,', \\
\hline Acroscler & osis & 1 (1 male) & , , \\
\hline Rheumat & oid arthritis & 16 ( 5 males and 11 females) & ," \\
\hline Total & & 38 ( 1.2 males and 26 females) & ," \\
\hline
\end{tabular}

A six-month-old male child afflicted with subacute disseminated lupus erythematosus and said to have started having a high fever along with rash in the face and limbs five days after his birth came under examination. In the urine of this child, the excretion of 2,5D.H.P.P.A. was clearly confirmed and another positive proof was established for the fact that its excretion could be attributed to an error inherent in the patient.

Effect of $l$-tyrosine dosage on the clinical symptoms of collagen disease patients;

As shown in Table IV, aggravation was noticed in the clinical symptoms of 4 cases out of five.

In No. 5 case, subsequent to administration of $l$-tyrosine, occurred a rapid extention of the lesions, coupled with a remarkable increase of the creatine content in the urine from $31 \mathrm{mg} /$ day to $325 \mathrm{mg} /$ day. A slight decrease, however, was detected in the creatinine content. 
Table IV

\begin{tabular}{|c|c|c|c|c|c|c|}
\hline Case & Diagnosis & Name & Sex & $\begin{array}{l}\text { l-Tyrosine } \\
\text { dosage }\end{array}$ & $\begin{array}{c}\text { Subsequent } \\
\text { symptomatic } \\
\text { changes }\end{array}$ & $\begin{array}{c}\text { Subsequent } \\
\text { 2,5- } \\
\text { D.H.P.P.A. }\end{array}$ \\
\hline 1 & $\begin{array}{c}\text { Dermato- } \\
\text { myositis }\end{array}$ & M.S. & Male & $\begin{array}{l}1 \mathrm{~g} \text { a day } \\
\text { Administered } \\
\text { for two suc- } \\
\text { cessive days }\end{array}$ & $\begin{array}{l}\text { Fever-up }\left(38.0^{\circ} \mathrm{C}\right) \\
\text { and lesions ag- } \\
\text { gravated two days } \\
\text { after dosage test }\end{array}$ & Positive \\
\hline 2 & $\begin{array}{c}\text { Dermato- } \\
\text { myositis }\end{array}$ & Y.T. & $\begin{array}{l}\mathrm{Fe}- \\
\text { male }\end{array}$ & Same as above & Same as above & , \\
\hline 3 & $\begin{array}{l}\text { Subacute dis- } \\
\text { seminated } \\
\text { lupus ery- } \\
\text { thematosus }\end{array}$ & S.S. & , & $\begin{array}{l}1 \mathrm{~g} \text { a day } \\
\text { Administered } \\
\text { for one day } \\
\text { only }\end{array}$ & $\begin{array}{l}\text { Lesions became } \\
\text { reddish }\end{array}$ & ", \\
\hline 4 & $\begin{array}{l}\text { Weber- } \\
\text { Christian's } \\
\text { disease }\end{array}$ & K.W. & ," & $\begin{array}{l}1 \mathrm{~g} \text { a day } \\
\text { Administered } \\
\text { for three suc- } \\
\text { cessive days }\end{array}$ & No change & , \\
\hline 5 & $\begin{array}{l}\text { Diffuse } \\
\text { scleroderma }\end{array}$ & S.I. & , & $\begin{array}{l}1 \mathrm{~g} \text { a day } \\
\text { Administered } \\
\text { for one day } \\
\text { only }\end{array}$ & $\begin{array}{l}\text { Fever-up with ex- } \\
\text { tension of lesions } \\
\text { and remarkable } \\
\text { increase of the } \\
\text { creatine content } \\
\text { in the urine after } \\
\text { dosage }\end{array}$ & ," \\
\hline
\end{tabular}

Genetical investigation. This investigation was made in regard to three different family lines. In all, 20 persons were examined and the results without exception proved negative. The results obtained showed that no excretion of 2,5-D.H.P.P.A. could be detected in any family-member completely free from symptoms of collagen disease.

Miscellaneous. The writers obtained the negative results in healthy males and females, each group consisting of 10 , and the results were the same when administered $1 \mathrm{~g}$ of $l$-tyrosine to them.

Seven cases, in all, were tested in regard to erythema nodosum, erythema multiforme, sepsis, and acute nephritis which are generally considered to be correlated with collagen disease. The results proved negative in all of them. Similarly, the examination of 25 more cases of various skin diseases, malignant neoplasmas, and lymphomas, all of which are not in the nature of collagen disease, produced negative results. In regard to erythema multiforme, eczema, contact dermatitis, and psoriasis vulgaris, six cases were put to dosage test and the same results obtained without exception.

Consideration. 2,5-D.H.P.P.A. has never been found in the urine of a human being and regarded hitherto rather as an intermediary metabolite of phenylalanine and tyrosine, viz, an imaginary, instead of really existent, substance. From the writers' experiments, however, it is now clear, that the substance is constantly excreted in the urine of the patients afflicted with collagen disease the etiology of which is still unknown and that none of it is to be found in the urine of their unafflicted family-members as well as in that of other healthy people. 
Indeed, this is a specific substance of collagen disease and common to all collagen disorders, besides. Consequently, the substance can be considered to be great value in correctly diagnosing the diseases of this category. Viewed from the writers' experiments in which tyrosine dosage unfailingly aggravated the clinical signs of collagen disease patients and that 2,5-D.H.P.P.A. is constantly excreted in their urine, it is possible to infer that the block of the intermediary metabolism of phenylalanine and tyrosine at its metabolic stage from 2,5-D.H.P.P.A. to homogentisic acid is one of the important etiological factors of the disease and that disorders of this kind are all induced with various other acquired factors added to it. Since the four maladies resulting from the metabolic blocks of phenylalanine and tyrosine are all found to be due to some error inherent in patients, the excretion of 2,5D.H.P.P.A. in the urine may possibly be imagined to be attributable to the absence of enzymatic action congenital to them. And this leads to the conclusion that collagen disease is closely correlated with the metabolic block of phenylalanine and tyrosine inherent in patients. The writers are convinced that a biochemical clue has now been found to the etiology of collagen disease.

We wish to express sincere gratitude to Dr. Yashiro Kotake, Dean of Wakayama Medical College, Dr. R. Iwatsuru, Director of the Attached Hospital, Prof. Yahito Kotake for their constant guidance, to Prof. K. Ichihara of the Biochemistry Department of Osaka University for his gift of synthetic 2,5-D.H.P.P.A. and to various hospitals from which we were offered necessary samples of urine.

\section{References}

1) Klemperer, P., Pollack, A. D., and Baehr, G.,: J. A. M. A., 119, 331 (1942).

2) Baehr, G., and Pollack, A. D.,: J. A. M. A., 134, 1169 (1947).

3) Klemperer, P.,: Ann. Int. Med., 28, 1 (1948).

4) Klemperer, P.,: Am. J. Path., 26, 505 (1950).

5) Klemperer, P., Gueft, B., Lee, S. L., Leuchtenberger, C., and Pollister, A. W.,: Arch. Path., 49, 503 (1950).

6) Neubauer, O.,: Deut. Arch. f. klin. Med., 95, 211 (1909).

7) Neubauer, O., und Falta, W.,: Hoppe-Seyler's Z., 42, 81 (1904).

8) Takeda, Y., Sujishi, K., Hara, M., and Tanaka, T.,: Med. J. Osaka Univ., 3, 313 (1952).

9) McElroy, W. D., and Glass, H. D.,: A Symposium on Amino Acid Metabolism, Baltimore, The Johns Hopkins Press, 836 (1955). 